40 Richman, D. D., and Wahl, G. M., Nucleic acid probes to detect viral diseases, in: Concepts in Viral Pathogenesis, II, pp. 301-309. Eds A. L. Notkins and M. B.A. Oldstone. Springer, New York-BerlinHeidelberg 1986.

41 Rindler, M.J., Ivanov, I. E., Plesken, H., Rodriguez-Boulan, E., and Sabatini, D. D., Viral glycoproteins destined for apical or basolateral plasma membrane domains traverse the same Golgi apparatus during their intracellular transport in doubly infected Madin-Darby canine kidney cells. J. Cell Biol. 98 (1984) 1304-1319.

42 Rodriguez-Boulan, E.J., and Sabatini, D.D., Asymmetric budding of viruses in epithelial monolayers: a model for the study of epithelial polarity. Proc. natl Acad. Sci. USA 75 (1978) 5071-5075.

43 Rubin, D.H., and Fields, B. N., The molecular basis of reovirus virulence: the role of the M2 gene. J. exp. Med. 152 (1980) 853-868.

44 Scheid, A., and Choppin, P.W., Identification of biological activities of paramyxovirus glycoproteins. Activation of cell fusion, hemolysis, and infectivity by proteolytic cleavage of an inactive precursor protein of Sendai virus. Virology 57 (1974) 475-490.

45 Scholtissek, C. Influenza A viruses with noncleaved hemagglutinin are not internalized after adsorption. Archs Virol. 90 (1986) 159-163.

46 Shafritz, D. A., Shouval, D., Sherman, H. I., Hadziyannis, S. J., and Kew, M.C. Integration of hepatitis B virus DNA in the genome of liver cells in chronic liver disease and hepatocellular carcinoma. New Engl. J. Med. 305 (1981) 1067-1073.

47 Sharpe, A.H., Chen. L. B., and Fields, B.N., The interaction of mammalian reoviruses with the cytoskeleton of monkey kidney CV-1 cells. Virology 120 (1982) 399411.

48 Singer, R.H., Lawrence, J. B., and Villnave, C., Optimization of in situ hybridization using isotopic and non-isotopic detection methods. Bio Feature 4 (1986) 230 249.

49 Sixbey, J.W., Vesterinen, E.H., Nedrud, J.G., Raab-Traub, N., Walton, L.A., and Pagano, J.S., Replication of Epstein-Barr virus in human epithelial cells infected in vitro. Nature 306 (1983) 480-483.

50 Skehel, J., Bayley, P., Brown, E., Martin, S., Waterfield, M., White,
J., Wilson, I., and Wiley, D., Changes in the conformation of influenza virus hemagglutinin at the $\mathrm{pH}$ optimum of virus-mediated membrane fusion. Proc. natl Acad. Sci. USA 79 (1982) 968-972.

51 Steeg, H. van, Kasperaitis, M., Voorma, H. A., and Benne, R., Infection of neuroblastoma cells by Semliki Forest virus. The interference of viral capsid protein with the binding of host messenger RNA's into initiation complexes is the cause of the shut-off of host protein synthesis. Eur. J. Biochem. 138 (1984) 473-478.

52 Tashiro, M., and Homma, M., Pneumotropism of Sendai virus in relation to protease-mediated activation in mouse lungs. Infect. Immun. 39 (1983) 879 - 888 .

52a Tashiro, M., Ciborowski, P., Klenk, H.-D., Pulverer, G., and Rott, R., Role of Staphylococcus protease in the development of influenza pneumonia. Nature 325 (1987) 536-537.

53 Trachsel, H., Sonenberg, N., Shatkin, A. J., Rose, J. K., Keong, K., Bergman, J.E., Gordon, J., and Baltimore, D., Purification of a factor that restores translation of vesicular stomatitis virus mRNA in extracts from poliovirus infected HeLa cells. Proc. natl Acad. Sci. USA 77 (1980) 770-774.

54 Tycko, B., and Maxfield, F.R., Rapid acidification of endocytic vesicles containing $\alpha_{2}$-macroglobulin. Cell 28 (1982) 643-651.

55 Weck, P. K., and Wagner, R. R., Inhibition of RNA synthesis in mouse myeloma cells infected with vesicular stomatitis virus. J. Virol. 25 (1978) 770-780.

56 Wolf, J. L., and Bye, W.A., The membranous epithelial (M)cell and the mucosal immune system. A. Rev. Med. 35 (1984) 95-112.

57 Yamada, A., Tsurudome, M., Hishiyama, M., and Ito, Y., Inhibition of host cellular ribonucleic acid synthesis by glycoprotein of Mumps virus. Virology 135 (1984) 299--307.

$0014-4754 / 87 / 11 / 121185-05 \$ 1.50+0.20 / 0$

(C) Birkhäuser Verlag Basel, 1987

\title{
Molecular biological methods in the diagnosis of viral disease
}

\author{
by $\mathrm{H}$. Wolf \\ Max von Pettenkofer Institute, University of Munich, Molecular and Tumorvirology, Pettenkoferstrasse $9 a, D-8000$ Munich 2 \\ (Federal Republic of Germany)
}

Summary. Molecular biology allowed considerable improvements in diagnostic procedures by production of new and more specific sonds for the detection of traces of viruses, both on the nucleic acid and protein levels, and by determining the immune response of the host to specific antigens. Improvements in sensitivity and improved correlation to the stage of viral disease are already evident from several applications and strongly suggest a broad application of these approaches.

Key words. Nucleic acid hybridization; synthetic peptides; computer analysis; antigen selection; recombinant antigens; rapid diagnosis.

\section{Introduction}

Development of virus-specific therapy and the need for fast differential diagnosis for intensive medical care challenge quick diagnosis which should also allow conclusions for the stage of disease.

Classic methods of viral disease diagnosis are based on the cultivation of agents, direct demonstration of viral antigens, e.g., by immunofluorescence, and the detection of specific antibodies. Many of the procedures currently in use have the disadvantage that the reading of results requires well-trained personnel and disease-related advice is often not given or comes too late. This is particularly true for chronic neoplas tic or reactivated acute virus-related diseases. Additional problems arise, e.g. form Hepatitis B, through long transitions from antigen or antibody excesses in connection with a complete exclusion of remaining infectiosity.

\section{Detection of genetic material of viruses by nucleic acid hybridi- zation}

Considerably influenced by the findings of tumor virology, i.e., that viruses persist in cells and can change these without

\section{LABELS:}

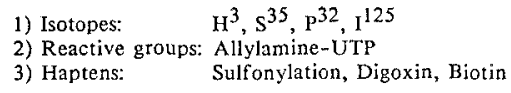

INTRODUCTION OF LABELS:

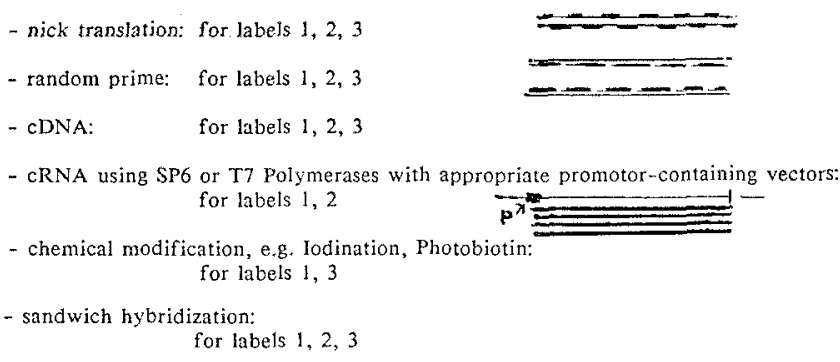

Figure 1. Introduction of label in nucleic acids for use as hybridization probe $^{1,7,8,13,14,16,19,23,24}$. 
Serologic parameter of EBV-related diseases based on specific proteins produced by recombinant DNA technology.

\begin{tabular}{|c|c|c|c|c|}
\hline Diagnosis & Antibody class & Antigen (ag-complex) & Antibody class & Antigen (ag-complex) \\
\hline \multirow[t]{2}{*}{ Acute infection } & $\operatorname{IgM}$ & BMRF-1(EA) & $\operatorname{IgG}$ & BMRF-I(EA) \\
\hline & $\operatorname{Ig} M$ & $\mathrm{BcLF}-1(\mathrm{VCA})$ & & \\
\hline \multirow[t]{2}{*}{ Past infection } & $\lg G$ & $\mathrm{BcLF}-1(\mathrm{VCA})$ & & \\
\hline & $\lg G$ & BKRF-1(EBNA-1) & & \\
\hline \multirow[t]{2}{*}{ Chronic infection } & $\operatorname{IgG}$ & BcLF-1(VCA) & & \\
\hline & (in absence of $\mathrm{I}$ & RF-1 (EBNA-1) and/or & MA as well as Ig! & $(F-1)$ \\
\hline Nasopharyngeal carcinoma & $\operatorname{Ig} \mathrm{A}$ & BALF-2(EA) & $\operatorname{IgA}$ & BLLF-1(MA) \\
\hline
\end{tabular}

\begin{tabular}{lccc}
\hline & total & \multicolumn{2}{c}{ HBV-DNA pos. } \\
& $N$ & $N$ & 8 \\
\hline HBE AG pos. & 1051 & 805 & $77(20-100)$ \\
Anti HBE pos. & 360 & 141 & $16(=-64)$ \\
$\begin{array}{l}\text { HBE AG neg., } \\
\text { Anti HBE neg. }\end{array}$ & 175 & 36 & $21(0-47)$
\end{tabular}

Figure 2. Detection of HBV-DNA in serum with various serological parameters (Seelig et al. ${ }^{20}$, including some of our own unpublished data).

the presence of structural proteins, the detection of viral nucleic acids was seen as a useful test for acute and chronic active diseases.

For this method to be widely used, the availability of appropriate probes leaving a detectable signal is an absolute requirement. Several methods have been applied to introduce a label into virus-specific DNA segments, derived almost exclusively from segments of the viral genomes cloned into the appropriate plasmid vectors. As a detection system, $\left[{ }^{32} \mathrm{P}\right]-1 \mathrm{a}-$ beled nucleic acids together with autoradiography are frequently used because of their low price and high-signal density. Non-radioactive detection systems are being increasingly applied as the sensitivity is gradually improved and the possibilities of long-term storage and reduced environmental pollution are solved (fig. 1). The requirement to have a multitude of specific probes can cause logistic problems. Introduction of specific sequences in bacteriophages with single-stranded DNA in combination with labeled universal probes to the phage portion allows the economic establishment of a large collection of unlabeled yet detectable probes ${ }^{24}$.

In the case of Hepatitis B, viral DNA in serum can be detected with simple procedures. Serum samples can be applied to simple filtration units or directly to membrane filters and tested for nucleic acids. Evaluation of test series from several laboratories demonstrates that nucleic acid hybridization is the best proof of potential infectiosity of patients ${ }^{20}$ (fig. 2). The difficulties in the diagnosis of acute diseases becomes evident with the demonstration of cytomegalovirus in immunosuppressed individuals such as organ transplant recipients or those infected by human immunodeficiency virus (HIV). Several methods have been compared. Virus isolation is too slow in any case. Short-term culture and detection of viral antigens or nucleic acids in these cultures have a considerably accelerated diagnosis which is important in the face of virusspecific therapy. Because testing of several samples is usually little more work compared to tests with single samples, it seems worth the consideration to routinely screen over longer periods persons at high risk for cytomegalovirus infection for virus release.

Using the example of bone marrow transplant patients, considerable variations of virus load could be demonstrated ${ }^{11,13}$ A coordination of immunosuppressive therapy and/or antiviral therapy is possibly more effective than waiting for the viral disease to reach its final stages. Important for cytomegalovirus-related diagnosis is the use of specific segments of viral DNA as a probe for several regions of viral DNA cross-reacted with human DNA. In addition, care must be taken to avoid false-positive results by incorrect preparation of test samples ${ }^{13}$.

Demonstration of viral nucleic acids is of interest and importance for virus-associated neoplasias of man, papillomavirus-associated carcinomas (e.g. of the cervix uteri) and Epstein-Barr virus (EBV)-associatd nasopharyngeal carcinoma (NPC) in particular. Detection of viral genomes can be done as described in figure 3. Cellular material can be obtained from biopsies, swabs ${ }^{10}$ or collected with the help of simple aspiration devices ${ }^{18}$.

Frequently the distinction, whether tissue or lymph nodes represent malignant or benign growth or reactive processes, is difficult. In the case of virus-associated condition, the status of viral nucleic acids may allow important conclusions. DNA of papillomavirus, for example, is integrated into the host genome (fig. $4 \mathrm{C}$ ) in a specific manner while it is still present as a circular molecule (fig. 4B) in warts and condylomas ${ }^{4}$. DNA of EBV in lymphoma cells is present in a

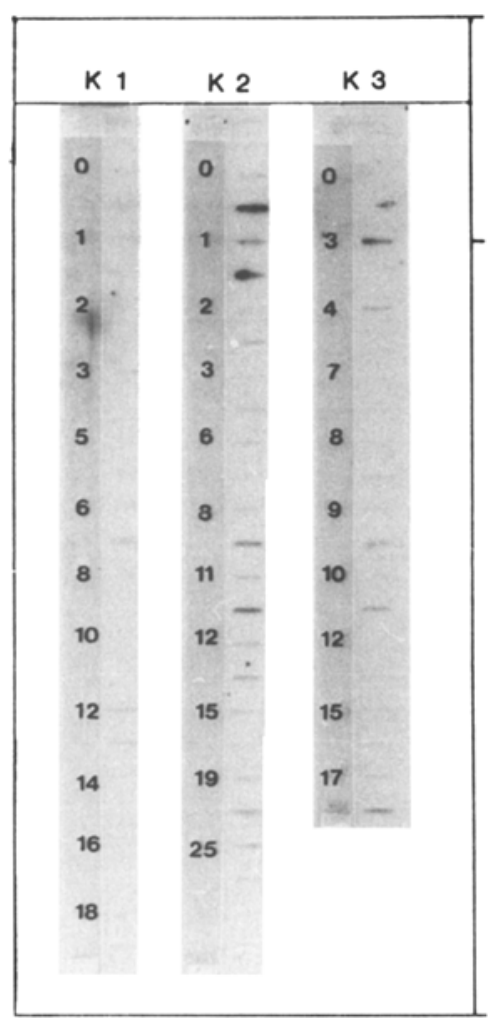

Figure 3. Nucleic acid hybridization for the detection of cytomegalovirus with urine samples of bone marrow transplant recipients. A low speed and a high speed pellet were prepared in consecutive order from $5 \mathrm{ml}$ of urine collected at the weeks post transplantation given at each lane. For each sample low speed and high speed pellets are tested using a cloned fragment of CMV-DNA ${ }^{13}$. A sample was considered positive when the high speed pellet yielded a stronger signal than the low speed pellet. K1-K3 represent samples taken from three different patients. 
circular form (fig. 4B) while cells replicating virus contain linear viral genomes (fig. 4A). Differentiation of these forms of viral DNA can help to distinguish malignant proliferative from reactive forms.

The tissues to be tested can be analyzed with the help of restriction enzymes for the presence of linear, circular or integrated viral DNA (fig. 4).

For diseases involving latency, sensitivity of detection can be a serious problem. Besides considerable progress in introduction and detection of signals in the hybridization probe (fig. 1) ${ }^{2}$, specific amplification of the relevant (viral) sequences in the test material has been developed as a powerful enhancement of sensitivity (fig. 4$)^{12}$. The principle of the test $^{12}$ involves the addition of (synthetic) oligonucleotides complementary to two areas of both strands leaving a space of a few hundred nucleotides in between. The 'gap' can be filled in the presence of the Klenow fragment of DNA polymerase and nucleosidetriphosphates. The use of heat-stable DNA polymerase ( $T$.aquaticus) allows several consecutive cycles of amplification by a sequence of heating and annealing/sequencing steps (fig. 5).

In the case of NPC it was necessary to correlate the presence of viral nucleic acid with the epithelial tumor cells. This was possible using frozen tumor sections and hybridizing viral DNA to the viral sequences in situ followed by autoradiography $^{22}$. This powerful technique was used for a multitude of questions and, with appropriate improvements ${ }^{5}$, has been very useful for elucidation of pathogenetic mechanisms as shown for sudden deafness of $\operatorname{man}^{6}$.

\section{Immunological procedures}

Classic serological procedures are not at all reduced in the overall importance by the possibilities of nucleic acid hybridization; rather, it becomes evident that inclusion of antibody class-specific tests and the use of well-characterized antigen systems allows considerably improved diagnostic judgement. For example, it was possible to develop test systems for the EBV-related NPC, which allows early diagnosis and which leads to considerable improvements of prognosis. The increasing force for rationalization in the laboratories and the desire for exact documentation can only be fulfilled when pure antigens permitting machine-readable tests are available.

Gene technological methods and chemical synthesis of segments of viral gene products offer the possibility of pure reagents, even for those agents which are difficult to grow in tissue culture.

A

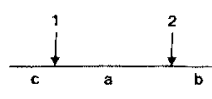<smiles>CC1CCCCCCC(I)C1</smiles>
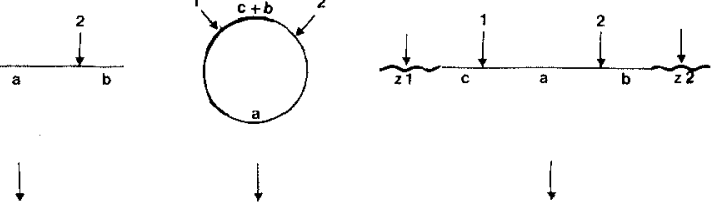

a....

$\longrightarrow b$

Figure 4. Detection of the stage of viral DNA in infected tissue. Extracted total DNA is digested with the appropriate restriction enzymes, electrophoretically separated by molecular weight on agarose gels, transferred to membranes and hybridized with a specific fragment of the viral genome. The hatched band will be the only one visible in the excess of cellular DNA through the hybridization detection and by its molecular weight directed location allow the distinction of the stages of viral DNA ${ }^{17}$.

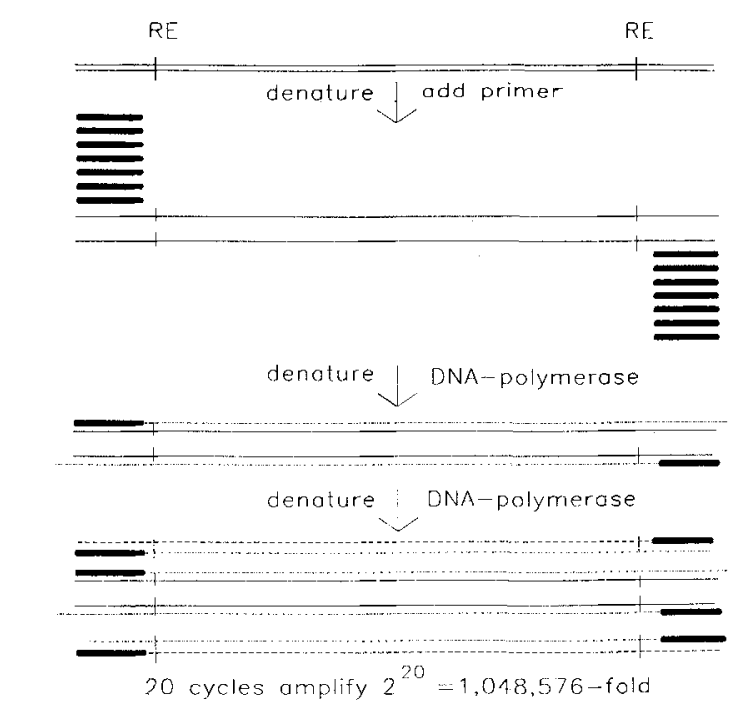

Figure 5. Amplification of selective segments of DNA in test material. RE: restriction enzyme site.

The value of these techniques will be explained on the example of diagnosis of EBV and HIV-related diseases. Immunofluorescence only rarely allows detection of antibodies for specific proteins because these tests are neither machinereadable nor available for documentation. Series of immunoprecipitations with radioactive-labeled EBV-infected cells using sera from NPC patients, patients with infectious mononucleosis and sera from healthy EBV antibody-positive individuals were made in order to identify those viral proteins which seemed useful for identification of the particular health status due to the regular presence of the respective antibodies.

Parallel to the selection of antigens, proteins were mapped on the viral genome using hybridselected translation ${ }^{2}$. The identified genes were then cloned into bacterial plasmids such that transfected bacteria would produce these products. Because many viral proteins are not stable in heterologous expression systems, strategies were developed which allowed the identification of those protein segments responsible for their recognition by the immune system and to selectively express these segments (fig. 6$)^{15}$. Repeated application of this

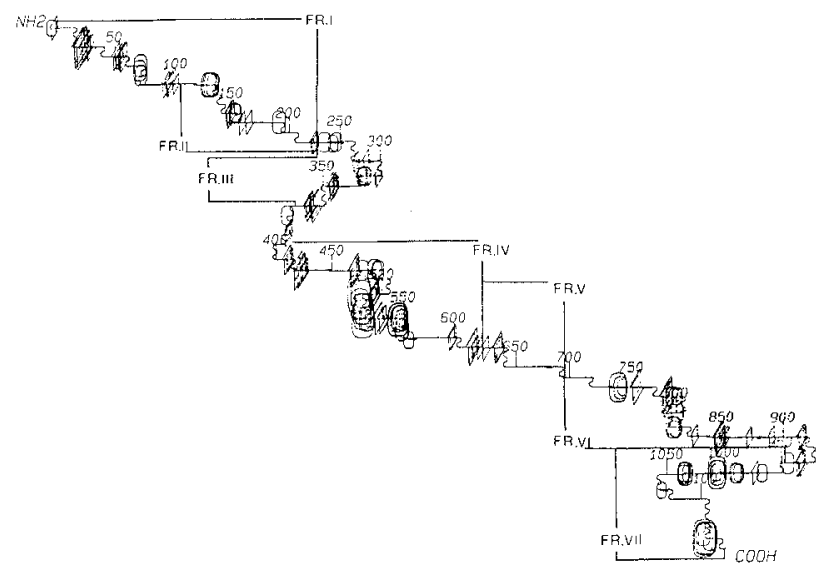

Figure 6. Computer analysis of an EBV gene (p138; BALF-2 EA). Prediction of secondary structure ( $\alpha$ helix $\sim$, pleated sheet WW, random coil $M$ and $\beta$-turn 3 ) with various aigorithms (e.g. Refs. 3, 9) are superimposed with further parameters, here hydropathy ( $O$ hydrophilic, $\checkmark$ hydrophobic). Areas with $\beta$-turns in hydrophilic environment were found to be preferred areas for eliciting humoral immune response ${ }^{25}$. FR I-VII: subcloned fragments of the p138 gene. 
technology allowed the development of antigen kits which permit diagnosis of various diseases caused by EBV (table) The described approach is of special importance also for diagnosis of HIV infections. Because Western blots derived from viruses are often difficult to interpret due to the presence of diffuse bands of glycoproteins and variations in quality. With respect to the security concerns for mass cultures of HIV, tests have been developed on the basis of recombinant products. A combination of such products allows definite diagnosis even in questionable cases (Soutschek-Bauer, Motz and Wolf, in prep.). At the same time recombinant antigens, which may contain the major antigenic determinant of viral proteins, can be the source of inexpensive and simple first screening tests (Motz, Soutschek-Bauer and Wolf, in prep.).

One alternative to antigens produced by gene technology is the chemical synthesis of peptides. A disadvantage of this method is that only short segments of a protein can be represented. Application of appropriate computer programs for epitope selection and the use of several antigens in one test can very effectively limit these disadvantages ${ }^{25}$. An advantage of this method is that no problems with foreign antigens exist and that antigens become available shortly after a sequence of a gene is finished. This then becomes particularly evident when a new technique for synthesis is used. With this method peptides are linked via ester bondage so stably to the carrier that they remain bound even through removal of the protective groups (Modrow and Wolf, in prep.). It is a feature of this method that peptides need not be removed from the carrier followed by time-consuming purification and consequent binding to surfaces which always causes the reduction of antigenicity. Thus fast and inexpensive test systems can be developed when simple pieces of equipment such as the millititer system from Millipore is used (fig. 7).

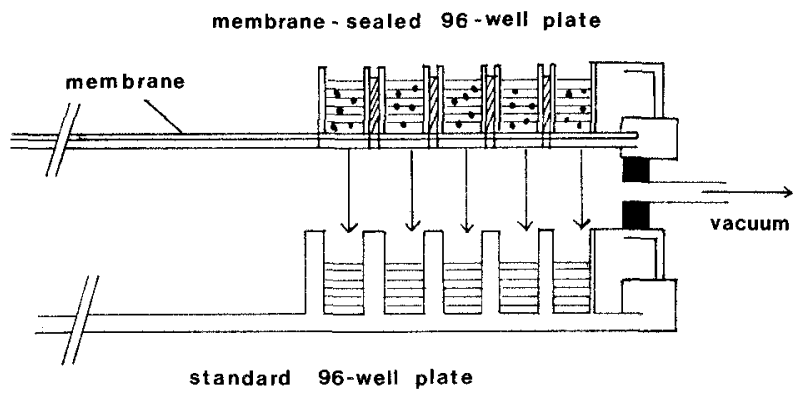

Figure 7. Solid phase ELISA test with peptide antigen coupled to resin beads (Modrow and Wolf, in prep.). Using modifications of Fmoc and tBoc chemistry of peptide synthesis resins containing deprotected oligopeptides can be produced. These particles can be used in suspension to react with antibodies from serum samples and thus allow the development of diagnostic tests. The use of microtiter plates with membrane-mounted bottom including a fitted suction device for both incubation and washing greatly facilitates this technique of antibody detection.

1 Arrand, J.E., Preparation of single-stranded cDNA probes, in: $\mathrm{Nu}$ cleic Acid Hybridisation - a Practical Approach, pp. 20-21. Eds B. D. Hames and S. J. Higgins. IRL Press, Oxford-Washington DC 1985

2 Burns, J., Chan, V.T. W., Jonasson, J. A., Fleming, K. A., Taylor, S., and McGee, O.D., Sensitive system for visualising biotinylated DNA probes hybridised in situ: rapid sex determination of intact cells. J. clin. Path. 38 (1985) 1085-1092.

3 Chou, P.Y., and Fasman, G. D., Prediction of the secondary structure of proteins from their amino acid sequence. Adv. Enzym. 47 (1978) 45-148.

4 Dürst, M., Schwarz, E., and Gissmann, L., Integration and persistence of human papillomavirus DNA in genital tumors, in: Viral Etiology of Cervical Cancer, pp. 273-280. Eds R. Peto and H. zur Hausen. Banbury Report 21, Cold Spring Harbor Laboratory 1986.

5 Falser, N., Bandtlow, I., Haus, M., and Wolf, H., Detection of PRV-DNA in the inner ear of intranasally infected BAL-B-C mice with nucleic acid hybridization in situ. J. Virol. 57 (1986) 335-339.

6 Falser, N., Bandtlow, I., Rziha, A., Bauer, G., Pöppel, S., Haus, M., and Wolf, H., Reactivation of PRV infection of swine: A model for sudden deafness of man? Zbl. Bakt. Mikrobiol. Hyg, in press.

7 Feinberg, A.P., and Vogelstein, B., A technique for radiolabeling DNA restriction endonuclease fragments to high specific activity. Analyt. Biochem. 132 (1983) 6⒔

8 Forster, A.C., McInnes, J.L., Skingle, D.C., and Symons, R.H., Non-radioactive hybridization probes by the chemical labelling of DNA and RNA with a novel reagent, photobiotin. Nucl. Acids Res. $13(1985)$ 745-761.

9 Garnier, J., Osguthorpe, O. J., and Robson, B., Analysis of the accuracy and implication of simple methods for predicting the secondary structure of globular proteins. J. molec. Biol. 120 (1978) 97-120.

10 Gissmann, L., and Schneider, A., Diagnosis of papillomaviurs infection by nucleic acid hybridization, in: Rapid Methods and Automation in Microbiology and Immunology, pp. 43-47. Ed. K.-O. Habermehl. Springer, Berlin--Heidelberg-New York-Tokyo 1985.

11 Kubanek, B., Ernst, P., Schäfer, U., Ostendorf, P., and Wolf, H., A controlled trial of intravenous hyperimmuneglobin in the prevention of cytomegalovirus infection in bone marrow transplant recipients. Exp. Hemat. 12 (1984) 111-112

12 Kwok, S., Mack, D. H., Mullis, K. B., Poiesz, B., Ehrlich, G., Blair, D., Friedman-Kien, A., and Skninsky, J.J., Identification of human immunodeficiency virus sequences by using in vitro enzymatic amplification and oligomer cleavage detection. J. Virol. 61 (1987) 16901694

13 Leser, U., Testung und Etablierung einer Methode für die Nukleinsäurehybridisierung bei menschlichen Herpesviren (Schwerpunkt: Cytomegalievirus) mit klinischen Materialien. Thesis, LMU-München (1985).

14 Melton, D. A, Krieg, P. A., Rebagliati, M. R., Maniatis, T., Zinn, K., and Green, M.R., Efficient in vitro synthesis of biologically active RNA and RNA hybridization probes from plasmids containing a bacteriophage SP6 promoter. Nucl. Acids Res. 12 (1984) 7035 7056

15 Motz, M., Fan, J., Seibl, R., Jilg, W., and Wolf, H., Expression of the Epstein-Barr virus $138-\mathrm{kD}$ a early protein in Escherichia coli for the use as antigen in diagnostic tests. Gene 42 (1986) 303 312.

16 Parichehre, D., Rosenberg, A.H., Dunn, J.J., and Studier, F. W., Cloning and expression of the gene for bacteriophage T7 RNA polymerase. Proc. natl Acad. Sci. USA 81 (1984) 2035-2039.

17 Raab-Traub, N., and Flynn, K., The structure of the termini of the Epstein-Barr virus as a marker of clonal cellular proliferation. Cell 47 (1986) 883-889.

18 Richter, W., Gu, S. Y., Seibl, R., and Wolf, H., A new method for examination of carcinomas of the nasopharynx, in: Nasopharyngeal Carcinoma: Current Concepts, pp. 25-32. Eds U. Prasad, D.V. Ablashi, P. Levine and G. Pearson. University Malaya Press, Kuala Lumpur 1983.

19 Rigby, P., Dieckmann, M., Rhodes, C., and Berg, P., Labeling deoxyribonucleic acid to high specific activity in vitro by nick translation with DNA polymerase I. J. molec. Biol. 113 (1977) 237-251

20 Seelig, R., Metzger, B., Renz, M., Metzger, P., and Seelig, H.P. Diagnostische Bedeutung des Nachweises von Hepatitis-B-VirusDNS bei akuten und chronischen Hepatitiden. Dtsch. med. Wschr. I10 (1985) 1968-1974.

21 Seibl, R., and Wolf, H., Mapping of Epstein-Barr virus proteins on the genome by translation of hybrid-selected RNA from induced P3HR I cells and induced Raji cells. Virology 141 (1985) 1-13.

22 Wolf, H., zur Hausen, H., and Becker, V., EB viral genomes in epithelial nasopharyngeal carcinoma cells. Nature New Biol. 244 (1973) 245-247.

23 Wolf, H., Haus, M., Leser, U., Modrow, S., Motz, M., Gu, S. Y., Falser, N., Bandtlow, I., Richter, W., and Pathmanathan, R., New developments in nucleic acid hybridization, in: Virus-associated Cancers in Africa, pp. 373-391. Eds A. O. Williams, G. T. O'Conor G.B. de Thé and C.A. Johnson. IARC Scientific Publications No. 63, Lyon, France 1984.

24 Wolf, H., Leser, U., Haus, M., Gu, S. Y., and Pathmanathan, R. Sandwich nucleic acid hybridization: A method with a universally usable labeled probe for various specific tests. J. virol. Meth. 13 (1986) $1-8$

25 Wolf, H., Modrow, S., Motz, M., Jameson, B., Hermann, G., and Förtsch, B., An integrated family of amino acid sequence analysis programs. CABIOS, submitted. 